\title{
NOTICE AND HEARING IN GOVERNMENT EXCLUSIONARY ACTION
}

In Homer v. Richmond ${ }^{1}$ and Dixon v. Alabama State Bd. of Educ., ${ }^{2}$ two United States courts of appeals have recently indicated the extent to which government must afford notice and hearing to persons who have been excluded from activities in which they have previously been engaged. In Homer, appellants, who were employed as radio-telegraph operators on board privately owned vessels of the United States Merchant Marine, applied to the Commandant of the Coast Guard ${ }^{3}$ to secure licenses certifying that they were "suitable and safe" to continue to be entrusted with the powers and duties of their employment. Their applications were denied ${ }^{4}$ on the ground that they were "affiliated with, or sympathetic to the principles of organizations, associations, groups and combinations of persons subversive or disloyal to the Government of the United States." 5 On the basis of a decision in an analogous case, ${ }^{6}$ appellants renewed their applications seven years later ${ }^{7}$ but were again denied certification; thereupon

1292 F.2d 719 (D.C. Cir. 1961).

2294 F.2d 150 (5th Cir.), cert. denied, 368 U.S. 930 (1961).

3 Appellants made application in compliance with revised regulatory legislation, 62 Stat. 232, 233 (1948), 46 U.S.C. $\$ \$ 229$ a, c (1958), which required radiotelegraph operators on Merchant Marine vessels to obtain a valid first- or second-class radiotelegraph operator license from the Federal Communications Commission and then to apply to the Coast Guard to be designated a licensed officer. 62 Stat. 233 (1948), 46 U.S.C. $\$ 229 \mathrm{c}$ (1958), provides: "[I]f, upon full consideration, they are satisfied that his character, habits of life, and physical condition are such as to authorize the belief that he is a suitable and safe person to be entrusted with the powers and duties of such a station, they shall grant him a license ...."

4 The Commandant appointed a board of officers to investigate appellants in accordance with the statutory standard. The Commandant concurred in the recommendation of the board and denied appellants' applications in 1949. Appellants were duly notified by letter and informed of their right under 46 C.F.R. $\$ 10.13-17$ (d) (3) (1953) to file a written request for reconsideration and of the material which would be deemed pertinent to such reconsideration. See Brief for Appellee, pp. 2-3.

5 Joint Appendix to Briefs of Appellants and Appellee, p. 104a. The application of one of the three appellants was denied because he did not possess the necessary FCC license.

6 Parker v. Lester, 227 F.2d 708 (9th Cir. 1955). This case held invalid provisions of regulations, issued by the President pursuant to the Magnuson Act, 64 Stat. 427 (1950), 50 U.S.C. 191 (1958), which established a security program authorizing the deprivation of employment to Merchant Marine seamen without notice or the opportunity to meet charges against them. Exec. Order No. 10173, 15 Fed. Reg. 7005 (1950), amended by Exec. Order No. 10277, 16 Fed. Reg. 7537 (1951), amended by Exec. Order No. 10352, 17 Fed. Reg. 4607 (1952).

. 7 Appellant Homer made no attempt to secure reconsideration after the initial denial; in 1952 appellant McCrea made an attempt to receive reconsideration but, since his affidavit contained no return address, no action was taken upon it; appellant Colcord in 1952 wrote a letter to the Commandant which failed to comply with the provisions for presentation of pertinent grounds for reconsideration under 46 C.F.R. $\$ 10.13-17$ (d) (3) (1953). 
they requested hearings which were also refused. In an action seeking a declaratory judgment that the regulations ${ }^{8}$ pursuant to which their applications had been denied were unconstitutional as applied to appellants, ${ }^{8}$ the district court, in a memorandum opinion, ${ }^{10}$ granted summary judgment for the defendant Commandant. The Court of Appeals for the District of Columbia reversed, holding that, although the procedure followed by the Coast Guard was expressly authorized by Congress, ${ }^{11}$ the denial of appellants' applications for licenses without some opportunity to answer charges was a violation of the fifth amendment due process clause..$^{12}$

In Dixon, students in a state college for Negroes, without prior notice or hearing, were notified by letter from the college president that they had been expelled by the Alabama State Board of Education; the apparent ${ }^{13}$ basis for expulsion was the students' alleged participation in various peaceful demonstrations ${ }^{14}$ in protest against racial segregation. ${ }^{15}$ On appeal from denial of injunctive relief against the State Board of

846 C.F.R. $\S 10.13-17$ (d) (1) (1953) authorizes the Commandant to reject an application "when derogatory information has been brought to his attention which indicates that the applicant's character and habits of life are such as to authorize the belief that he is not a suitable and safe person to be entrusted with the duties of radiotelegraph operator on any vessel."

9 While this action was pending in the district court, another board of officers reviewing appellants' cases concurred in the previous denials and made detailed findings which were adopted by the Commandant and were related with particularity by letter to each applicant. For the letters of March 27, 1959 from the Commandant to the three appellants, see Joint Appendix to Briefs of Appellants and Appellee, pp. 111a-14a, 122a-27a, 132a-34a.

10 The district court found that "each plaintiff, although not accorded an oral hearing, was afforded the opportunity to know and to meet the findings on which defendant's adverse action was based. Under the circumstances of this case as shown upon the record . . . there was no denial of due process or violation of constitutional guarantees." Homer v. Richmond, Civil No. 1541-48, D.D.C. March 23, 1960, in Joint Appendix to Briefs of Appellants and Appellee, pp. 143a-44a.

11 See note 3 supra.

12 Since the court noted that appellants did not renew their requests for hearings after the letters of March 27, 1959 from the Commandant, it is possible to view the court's action as remanding the case to the administrative officer to determine whether a hearing would be granted upon request of appellants. 30 GEo. WASH. L. REv. 123, $125 \mathrm{n} .24$ (1961). However, this interpretation seems unnecessarily and unreasonably narrow in light of the court's determination that the procedures employed by the government were not consonant with minimum due process requirements. See 292 F.2d at 724 .

13 The court noted that "the misconduct for which the students were expelled has never been definitely specified. Defendant Trenholm, the President of the College, testified that he did not know why the plaintiffs and three additional students were expelled .... The notice of expulsion ... mailed to each of the plaintiffs assigned no specific ground for expulsion, but referred in general to "this problem of Alabama State College." 294 F.2d at 151-52. The grounds mentioned in the text were stated in the testimony of Governor Patterson. Id. at 153. They seem to constitute the most reasonable explanation for the Board's action.

14 The court accepted the finding of the district court, Dixon v. Alabama State Bd. of Educ., $186 \mathrm{~F}$. Supp. 945, 947 (M.D. Ala. 1960), that all six appellants were present at a sit-in in the publicly owned lunch room in the basement of the county courthouse in Montgomery, Alabama, but that the evidence did "not affirmatively show that all of the plaintiffs were present at any but . . . [that] one demonstration." 294 F.2d at 152-53.

15 See generally Pollitt, Dime Store Demonstrations: Events and Legal Problems of First Sixty Days, 1960 Duke L.J. 315. 
Education and the college president, ${ }^{16}$ the Court of Appeals for the Fifth Circuit, one judge dissenting, ${ }^{17}$ reversed, holding that due process required a state to afford notice and hearing before a student at a public college could be expelled for such misconduct. 18

\section{Government Exclusionary Action}

Procedural due process cases ${ }^{19}$ relevant to Homer and Dixon have usually been discussed in three categories-public employment discharge

16 Dixon v. Alabama State Bd. of Educ., 186 F. Supp. 945 (M.D. Ala. 1960). Appellants sought a preliminary and permanent injunction to restrain the State Board of Education and the college president from obstructing their right to attend Alabama State College.

17 The dissenting opinion adopted the reasoning of the district court that since a student had no right to attend a state college, except as conditioned by his compliance with its scholastic and disciplinary requirements, the proper college authorities, in the interests of preserving ideals of scholarship or moral atmosphere, might formulate reasonable rules and regulations in the exercise of a broad discretion, with which courts should not interfere unless it were abused. 294 F.2d at 160-61.

18 Accord, Knight v. State Bd. of Educ., 200 F. Supp. 174 (M.D. Tenn. 1961), a recent case which followed the Dixon holding in determining that student freedom riders convicted of disorderly conduct in Mississippi could not be automatically expelled from their Tennessee state college without fair hearing to consider whether their convictions were ones "involving personal misconduct"-the standard established by the Tennessee State Board of Education-or merely a technical violation.

19 No case has squarely raised the issue of whether fifth and fourteenth amendment due process would require equal safeguards under the same circumstances, particularly in the more narrow area of due process in discharge, licensing, or security clearance cases. But cases dealing with the fifth and fourteenth amendments have cited both state and federal cases without recognition of any potential difference between them. For example, Greene v. McElroy, 360 U.S. 474, 492 (1959) (a fifth amendment case), cited Dent v. West Virginia, 129 U.S. 114 (1889), and Schware v. Board of Bar Examiners, 353 U.S. 232 (1957) (both fourteenth amendment cases), to substantiate the theory that the right to hold specific private employment is protected by the due process clause of the fifth amendment. Wieman v. Updegraff, 344 U.S. 183, 191-92 (1952) (a fourteenth amendment case), cited United Pub. Workers v. Mitchell, 330 U.S. 75, 100 (1947) (a fifth amendment case), to demonstrate that a court only begs the question in saying that there is no constitutionally protected right to public employment. Again, three Supreme Court Justices appear to have indicated that they consider there is no difference between the procedural protection required by the fifth and fourteenth amendment due process clauses. In Adamson v. California, 332 U.S. 46, 66 (1947) (concurring opinion), Mr. Justice Frankfurter stated: "It ought not to require argument to reject the notion that due process of law meant one thing in the Fifth Amendment and another in the Fourteenth." Moreover, although this statement was made in rejecting the suggestion that the fourteenth amendment due process clause incorporated the first eight amendments, and thus may not be a clear indication of Mr. Justice Frankfurter's views, the same Justice's concurring opinion in Hannah v. Larche, 363 U.S. 420, 491 (1960), uses fourteenth amendment cases to "strongly support" the fifth amendment decision. In another concurring opinion in Hannah v. Larche, supra at 493, Justices Harlan and Clark stated that "the principles established by ... [these two fourteenth amendment due process cases] are dispositive of the issues herein . . ." The implication is unmistakeable that the two clauses are equated as far as procedural protection is concerned. The majority's opinion in Hanmah (per Warren, C.J.) carefully avoided any implied or express determination of this issue by making no mention of the two fourteenth amendment cases except to note that the majority had chosen not to treat them. Id. at 451 n.31. Since the Court has failed to make any distinction between the fifth and fourteenth amendments in the procedural area and certain Justices have indicated their belief that none would be justified, it is appropriate not to resolve the cases into fifth and fourteenth amendment categories when discussing procedural due process. 
cases, licensing cases, and security clearance cases. ${ }^{20}$ This classification provides a convenient framework for analyzing the cases in terms of the usual degree of employment foreclosure resulting from the government exclusionary action in the typical case in each category. However, this categorization must not be permitted to obscure the basic distinction among the cases-the effect of the government exclusionary action upon the individual concerned in terms of total or partial foreclosure from his chosen field of employment. Often, when a government worker is discharged, even for security reasons, he loses, at most, the ability to hold public employment; his opportunities for private employment are relatively unaffected. However, in occupations in which the government acts as the major employer - the field of education, for example-or when the publicity attendant to firing might seriously stigmatize the discharged individual, the resultant foreclosure from employment may be almost totalor at least involve far more substantial economic prejudice than in most public employment discharge cases. ${ }^{21}$ Similarly, expulsion from a public college may result in great injury in terms of foreclosure from further education and impairment of employment opportunities. In licensing cases, in which the government acts not as an employer but as a regulator of the qualifications for an entire field of private employment to insure some federal interest, the resultant foreclosure is total. In cases not involving actual licenses, in which government action may cause the exclusion of a private worker from employment opportunities for failing to meet security requirements established by the government for that occupation, the foreclosure may be either partial or total, depending on whether government security clearance is only a prerequisite for a particular job or is required for any employment within an entire trade or profession. Accordingly, although the customary classification will be employed for convenience, cases will be analyzed with respect to the extent of foreclosure from employment. ${ }^{22}$

20 See Jaffe \& Nathanson, Administrative Law 574, 578, 591 (2d ed. 1961); cf. Davis, Administrative Law Text 131, 138, 139 (1959).

$21 \mathrm{~A}$ recent study based on personal interviews with public school teachers who had been discharged by the board of education as an outgrowth of their failure to answer questions before the House Un-American Activities Committee in 1953 and 1954 supports this contention. It concluded that several dismissed teachers were almost totally foreclosed from employment in the teaching profession, that those who were able to secure appointments in private schools suffered a substantial impairment to their income, and that all of those dismissed who were interviewed, with one exception, encountered substantial difficulty in obtaining any work and sustained a significant decrease in their earning capacity. Cohen, McCarthyism: Its Rise, Its Fall, Its Legacy, pp. 52-73, May 1960 (unpublished thesis in Biddle Law Library, University of Pennsylvania).

22 The cases have not always adhered to the distinction among licensing, public employment discharge, and security clearance cases. See, e.g., Cafeteria Workers v. McElroy, 367 U.S. 886, 894, 896-98 (1961) (security clearance case), discussing Homer v. Richmond, 292 F.2d 719 (D.C. Cir. 1961) (licensing case), Vitarelli v. Seaton, 359 U.S. 535 (1959), and Wieman v. Updegraff, 344 U.S. 183 (1952) (both cases involving public employment). 


\section{A. Public Employment Discharge Cases}

In Bailey v. Richardson, ${ }^{23}$ a classic case in the public employment area, a divided court of appeals held that, since there was no right to government employment which could qualify as "liberty" or "property" within the protection of the fifth amendment, a government civil servant in a nonsensitive position, who had received several formal hearings, could be discharged on grounds of disloyalty without the opportunity to know the identity of her accusers or to cross-examine them. ${ }^{24}$ The Supreme Court affirmed by an equally divided Court. ${ }^{25}$ Although a year later in Wieman v. Updegraff ${ }^{26}$ the Court expressly rejected this privilege doctrine as a test for determining the degree of due process protection constitutionally required, ${ }^{27}$ the public employment discharge cases generally have failed to

23182 F.2d 46 (D.C. Cir. 1950), aff'd per curiam by an equally divided Court, 341 U.S. 918 (1951).

24 The court of appeals stated that "due process of law is not applicable unless one is being deprived of something to which he has a right." $182 \mathrm{~F} .2 \mathrm{~d}$ at 58 . In Bailey petitioner sought the right of confrontation and cross-examination of those who had given evidence against her. She had already received a hearing. Therefore, this case was never direct authority for the proposition that due process does not require some hearing in order for the government to discharge its own employees for disloyalty reasons. Bailey has been extended far beyond its factual situation. See, e.g., Radford v. United States, 264 F.2d 709, 710 (5th Cir. 1959); Haynes v. Thomas, 232 F.2d 688, 690 (D.C. Cir. 1956); Jason v. Summerfield, 214 F.2d 273, 277 (D.C. Cir.), cert. denied, 348 U.S. 840 (1954).

25341 U.S. 918 (1951). In a case decided by the Supreme Court on the same day it affirmed Bailey, Mr. Justice Douglas expressed his views on Bailey: "Dorothy Bailey . . . was on trial for her reputation, her job, her professional standing. . To make that condemnation without meticulous regard for the decencies of a fair trial is abhorrent to fundamental justice." Joint Anti-Fascist Refugee Comm. v. McGrath, 341 U.S. 123, 180 (1951) (Douglas, J., concurring).

26344 U..S. 183 (1952).

27 Id. at 191-92. The Court held that discharge of teachers from a state university for refusing to take a loyalty oath, which encompassed innocent as well as knowing association, violated due process. Compare Adler v. Board of Educ., 342 U.S. 485 (1952), and Garner v. Board of Pub. Works, 341 U.S. 716 (1951), with Wieman v. Updegraff, 344 U.S. 183, 188-91 (1952). See also Service v. Dulles, 354 U.S. 363 (1957); Peters v. Hobby, 349 U.S. 331 (1955). Recent substantive due process cases have rejected the privilege doctrine by assuming that due process of law required some reasonable standards for discharge of state employees. Although these cases have reached different results on the issue of constitutionality, all recognized that the state cannot employ purely arbitrary practices in discharging its employees. None of the cases which found no constitutional violation relied upon the privilege doctrine as the basis for its holding. See Nelson v. County of Los Angeles, 362 U.S. 1 (1960); Lerner v. Casey, 357 U.S. 468 (1958), 57 Mice. L. Rev. 412 (1959); Beilan v. Board of Pub. Educ., 357 U.S. 399 (1958). Extremely hazy constitutional distinctions have been drawn, however. Compare Slochower v. Board of Higher Educ., 350 U.S. 551 (1956), 25 FoRDhaM L. REv. 526, and Board of Pub. Educ. v. Intille, $401 \mathrm{~Pa}$ 1, 163 A.2d 420, cert. denied, 364 U.S. 910 (1960), with Nelson v. County of Los Angeles, supra, and Beilan v. Board of Pub. Educ., supra. See generally 1960 U. ILL. L.F. 341. The Court at one time adhered to the doctrine that a right to public employment was not "property" within the meaning of the due process clause. See, e.g., Taylor v. Beckham, 178 U.S. 548 (1900); cf. Angilly v. United States, 199 F.2d 642 (2d Cir. 1952). See also Gardner, The Great Charter and the Case of Angilly v. United States, 67 HARv. L. REv. 1 (1953). The Court in Wieman did not explain whether the employee's protected interest in his job was "life, liberty, or property." For additional criticism of the privilege doctrine, see Davis, The Requirement of a Trial-Type Hearing, 70 HARv. I. REv. 193, 225-32 (1956); Brown \& Fassett, Security Tests for Maritime Workers: Due Process Under the Port Security Program, 62 YALE L.J. 1163, 1192-93 (1953); Note, 63 YALE L.J. 206, 223-29 (1953); Note, 61 YALE L.J. 171, 188-91 (1952); cf. BrowN, LOYALTY AND SECURITY 334-35 (1958). 
articulate what specific procedural or substantive practices will satisfy due process. ${ }^{28}$

\section{B. State College Expulsion Cases}

The right of notice and hearing before expulsion from public colleges ${ }^{29}$ has been affirmatively recognized by one county court opinion ${ }^{30}$ and in dictum; ${ }^{31}$ most cases have assumed such a right by determining that the hearing afforded was sufficient. ${ }^{32}$ On the other hand, it has generally been held that the right to expel lies within the broad discretion of the college governing authority, and its action will not be disturbed unless the exercise of discretion as to procedure or substantive grounds is clearly arbitrary. ${ }^{33}$ In Steier v. New York State Educ. Comm'r, ${ }^{34}$ the most recent case prior to Dixon, a court of appeals held that a complaint alleging that a student's dismissal from a city college was a violation of the equal protection and due process clauses of the fourteenth amendment failed to raise a federal question sufficiently substantial to support federal jurisdiction. However, the authority of this case as to notice and hear-

28 No case has yet held that the opportunity for confrontation and cross-examination must be given to a public employee discharged for loyalty-security reasons. Both Slochower v. Board of Higher Educ., supra note 27, and Wieman v. Updegraff, supra note 27 , while holding the government action lacking in due process, failed to state what substantive and procedural practices would be commensurate with due process of law. See generally Ass'N OF THE BAR OF THE CITY OF NEW York, Report of the Spectal Committee oN the Federal Loyalty-Security Program 174-80 (1956); Bontecou, The Federal Loyalty-Security Program (1953); Brown, Loyalty and Security (1958); Yarmolinsky, Case Studies in Personnel Security (1955) ; Krasnowiecki, Confrontation by Witnesses in Government Employee Security Proceedings, 33 NOTRE DAME LAw. 180 (1958).

29 It has been held that a student may be discharged from a private institution based on the waiver which he signed upon registration. See John B. Stetson Univ. v. Hunt, 88 Fla. 510, 102 So. 637 (1924) ; Anthony v. Syracuse Univ., 244 App. Div. 487, 231 N.Y. Supp. 435 (1928). But see Seavey, Dismissal of Students: "Due Process", 70 HARv. L. REv. 1406 (1957). See also Guillory v. Administrators of Tulane Univ., 203 F. Supp. 855, 859, 863 (E.D. La. 1962) (dictum).

30 Commonwealth ex rel. Hill v. McCauley, 3 Pa. County Ct. 77 (C.P. 1887). This case goes further than the textual statement, although not on due process grounds, by requiring an opportunity for the expelled student to meet his accusers. 31 See Gleason v. University of Minn., 104 Minn. 359, 116 N.W. 650 (1908) (dictum); State ex rel. Sherman v. Hyman, 180 Tenn. 99, 171 S.W.2d 822 (1942) (dictum), cert. denied, 319 U.S. 748 (1943). Contra, State ex rel. Ingersoll v. Clapp, 81 Mont. 200, 263 Pac. 433, cert. denied, 277 U.S. 591, error dismissed, 278 U.S. 661 (1928).

32 See, e.g., Tanton v. McKenney, 226 Mich. 245, 197 N.W. 510 (1924). See also Hamilton v. Regents of Univ. of Cal., 293 U.S. 245 (1934) (attendance at state university conditioned upon participation in ROTC program); Waugh v. Board of Trustees, 237 U.S. 589 (1915) (diploma refused if student is a member of banned fraternity). See generally Seavey, supra note 29.

33 See, e.g., Robinson v. University of Miami, 100 So. 2d 442 (Fla. Dist. Ct. App. 1958); Tanton v. McKenney, 226 Mich. 245, 197 N.W. 510 (1924); State ex rel. Ingersoll v. Clapp, 81 Mont. 200, 263 Pac. 433, cert. denied, 277 U.S. 591, error dismissed, 278 U.S. 661 (1928).

34271 F.2d 13 (2d Cir. 1959), cert. denied, 361 U.S. 966 (1960). Appellant's principle constitutional contention was that he had been denied substantive due process because of the arbitrary nature of his expulsion. Judge Clark, in dissent, found that the complaint justified jurisdiction by alleging a denial of equal protection and substantive due process but did not mention any colorable procedural grounds. Id. at 22 . 
ing ${ }^{35}$ is limited by the fact that the student was given extensive warnings and several formal hearings before he was expelled. ${ }^{36}$

\section{Licensing Cases}

In licensing cases dealing with a denial of the opportunity to engage in a chosen private profession, the courts have better articulated what procedural protection must be afforded. ${ }^{37}$ In Parker $v$. Lester, ${ }^{38}$ a court of appeals held that procedures, ${ }^{30}$ established under a security program authorized by Congress and the President, ${ }^{40}$ were deficient in due process because they deprived merchant seamen of their entire field of employment without providing for notice and fair hearing. The court, by facing the due process question without searching for the specific "liberty" or "property" deprivations, recognized sub silentio that the Bailey privilege doctrine failed to reach the crux of the problem. ${ }^{41}$ The appellants had been given an appellate-type hearing and the opportunity to present their own evidence before a local appeal board following the notice of government noncertification, but they were never apprised of the specific grounds for the government action, nor confronted with the Government's case. ${ }^{42}$ The court of appeals indicated that in order to deny appellants their chosen profession in accordance with due process of law, confrontation and crossexamination would here be required. ${ }^{43}$

35 See note 83 infra.

36 The majority, 271 F.2d at 18, is guilty of making the extremely sweeping statement which is cited in the dissent in Dixon, 294 F.2d at 164-65: "Education is a field of life reserved to the individual states. The only restriction the Federal Government imposes is that in their educational program no state may discriminate against an individual because of race, color or creed."

37 See Goldsmith v. United States Bd. of Tax Appeals, 270 U.S. 117, 123 (1926) (dictum). See also Schware v. Board of Bar Examiners, 353 U.S. 232 (1957); Konigsberg v. State Bar, 353 U.S. 252 (1957). Compare Minkoff v. Payne, 210 F.2d 689 (D.C. Cir. 1953), with Walker v. City of Clinton, 244 Iowa 1099, 59 N.W.2d 785 (1953). See generally Davis, sipra note 27 , at 262-74.

38227 F.2d 708 (9th Cir. 1955), 104 U. PA. L. REv. 703 (1956).

3915 Fed. Reg. 9327 (1950), as amended, 16 Fed. Reg. 817 (1951), as amended, 16 Fed. Reg. 6868 (1951), as amended, 16 Fed. Reg. 8846 (1951), as amended, 17 Fed. Reg. 658 (1952), as amended, 17 Fed. Reg. 5040 (1952), as amended, 18 Fed. Reg. 3418 (1953), as amended, 18 Fed. Reg. 6941 (1953). This last amendment was made by the Coast Guard to comply with the district court decree which the court of appeals found, in reversing, not sufficiently protective of the seamen's interests.

40 See note 6 supra.

41 Parker v. Lester, 227 F.2d 708, 717 (9th Cir. 1955), reversing 112 F. Supp. 433, 439 (N.D. Cal. 1953).

$42 I d$. at 711 . See also Yarmolinskx, op. cit. supra note 28 , at 57 . The court concurred in the trial court finding, $112 \mathrm{~F}$. Supp. at 439 , that "the board members, themselves, had no personal knowledge of the reliability and veracity of the informers . . " 227 F.2d at 711-12 n.6.

$43 \mathrm{Id}$. at 715-22. Compare the district court opinion, $112 \mathrm{~F}$. Supp. at 444 . The Coast Guard amended its regulations to provide for notice "as specific and detailed as the interests of national security shall permit ... [including] ... names, dates, and places in such detail as to permit reasonable answer," and hearing procedure in which the appellant will be given the opportunity to present evidence in support of his defense, to examine those witnesses appearing, and in which "every effort should be made to produce material witnesses to testify ..." in support of the Commandant's decision and to have these witnesses available for confrontation 


\section{Security Clearance Cases}

In Greene v. McElroy ${ }^{44}$-an example of total exclusion from a chosen profession because of government noncertification-, a high-ranking executive was foreclosed from highly skilled private employment because the government had revoked his security clearance. The Supreme Court buttressed the reasoning in Parker, stating in dictum that "the right to hold specific private employment and to follow a chosen profession free from unreasonable governmental interference comes within the 'liberty' and 'property' concepts of the Fifth Amendment." 45 In finding that the procedures whereby the individual had been excluded were unauthorized, the Court held that when the administrative action has raised "serious" due process problems, express presidential or congressional authorization, rather than mere implied sanction, is necessary to sustain the procedures used. $^{46}$ In public as well as private employment discharge cases, the Greene rule and dictum have begun to influence judicial examination of the protection accorded to those discharged. ${ }^{47}$ Greene had appeared before two government security boards for hearings at which, in response to questions posed by the boards, he was permitted to explain his prior activities but was never apprised of the contents or sources of secret reports

and cross-examination by the applicant. 33 C.F.R. $\$ 121.11$ (a), .19(f) (Supp. 1961). These procedures would have clearly been of some benefit to the appellants in Parker by permitting revelation of certain informants and their charges; but since the reports on which the appeal board and the Commandant based their determinations were supplied to the Coast Guard by an independent investigative agency, it is doubtful whether the source or the nature of this crucial information would have been disclosed.

44360 U.S. 474 (1959), 44 MINN. L. Rev. 771 (1960). See Rauh, Non-Confrontation in Security Cases: The Greene Decision, 45 VA. L. Rev. 1175 (1959); The Supreme Court, 1958 Term, 73 HARV. L. REV. 84, 196-200 (1959). See generally Note, Due Process and the "Right" to a Job, 46 VA. L. Rev. 323 (1960).

45360 U.S. at 492 (dictum). The Court held that the Defense Department had not been given authority by either Congress or the President to establish the program in question; therefore, it was unnecessary to reach the constitutional question. See id. at 509 (concurring opinion), in which Mr. Justice Harlan noted that the majority (per Warren, C.J.) "unnecessarily deals with the very issue it disclaims deciding."

46 Id. at 507.

47 Bland v. Connally, 293 F.2d 852, 857 (D.C. Cir. 1961), and Davis v. Stahr, 293 F.2d 860, 864 (D.C. Cir. 1961), two recent cases involving discharges of inactive reservists from military service under conditions less than honorable, have cited Greene as controlling their determinations that, in the absence of express authorization from Congress or the President, such discharges could not be granted on the basis of secret information not produced at hearings. In Cafeteria Workers v. McElroy, 367 U.S. 886, 889-90 (1961), the Court adhered to the Greene rule calling for express authorization from Congress or the President in order for the Government to cause an employee's discharge without affording her full procedural protection. In Reed v. Franke, 297 F.2d 17, 26-27 (4th Cir. 1961), a case involving an honorable discharge of a veteran seaman for "unsuitability," a court of appeals examined the Greene dictum but found it not "controlling" since Congress had accorded procedural protection sufficient to satisfy due process by providing for a subsequent appeal with full hearing before a board of review. Beard v. Stahr, 200 F. Supp. 766, 775 (D.D.C. 1961), vacated with directions to dismiss, 30 U.S.L. Weer 3870 (U.S. May 28, 1962), distinguished the Greene dictum as not requiring confrontation and cross-examination of adverse witnesses before an army officer could be dismissed through administrative proceedings. 
on which most of the allegations and the final determination were based or confronted by the Government's case. The Government based its action on confidential information that Greene had associated with known sympathizers of the Communist party and belonged to and supported suspect groups. Strong language in the Court's opinion stressed the right to confrontation and cross-examination under these circumstances. ${ }^{48}$

Last term, in Cafeteria Workers v. McElroy, ${ }^{49}$ a closely divided Court ${ }^{50}$ seemingly retreated from the dictum, although not the rule, in Greene ${ }^{51}$ by holding that a short-order cook, employed in a private cafeteria on a military installation, was not denied due process of law under the fifth amendment in being summarily deprived of access to the installation for security reasons ${ }^{52}$ under a duly authorized security program ${ }^{53}$ which did not provide for notice or hearing. Again, the Court did not

48360 U.S. at $496-99$ (dictum). Without such procedural protection it would seem that when the board chooses to believe the informants rather than the applicant, he cannot adequately defend himself. Support was given to this contention following the Greene decision when the President promulgated a new set of regulations for "Safeguarding Classified Information Within Industry." Exec. Order No. 10865, 25 Fed. Reg. 1583 (1960). These regulations in part provided for a written statement to the applicant with reasons for denial of access as "comprehensive and detailed as the national security permits," and the opportunity to examine witnesses who have supplied information adverse to him. Exec. Order No. 10865, $\S \S 3,4,25$ Fed. Reg. 1583 (1960). Also, the statements of such confidential witnesses may be received against the applicant without the opportunity for confrontation or cross-examination only if the head of the department which supplied the information certifies that it was gathered by a confidential agent, the disclosure of whose identity "would be substantially harmful to the national interest," and if the head of the department administering the program finds the statement "reliable and material" and that failure to receive it would "be substantially harmful to the national security . . Exec. Order No. 10865, § 4(a) (1), (2), 25 Fed. Reg. 1583 (1960). The final decision on that applicant must then be made by the head of the department administering the program with due consideration for the lack of opportunity for the applicant to confront and cross-examine. Exec. Order No. 10865, \& 4(b) (2), 25 Fed. Reg. 1583 (1960). The ultimate situation is provided for in $\$ 9$ of these regulations:

Nothing contained in this order shall be deemed to limit or affect the responsibility and powers of the head of a department to deny or revoke access to a specific classification category if the security of the nation so requires. Such authority may not be delegated and may be exercised only when the head of a department determines that the procedures prescribed in sections 3 , 4 , and 5 cannot be invoked consistently with the national security and such determination shall be conclusive.

25 Fed. Reg. at 1584.

49367 U.S. 886 (1961), 36 N.Y.U.L. Rev. 506, 36 Notre Dame Law. 576.

50 Stewart, J., wrote for the five-justice majority; Brennan, J., wrote a dissenting opinion in which Warren, C.J., Black and Douglas, JJ., concurred.

51367 U.S. at 889-90. The Court expressly adopted the rule in Greene to test the legislative and executive authorization.

52367 U.S. at 888; see Brief for Petitioners, p. 7.

53 The Court found the security program authorized initially through the delegation to Congress in article I, $\$ 8$ of the Constitution and to the President in article II, $\$ 2$ of the Constitution, by 10 U.S.C. $\$ 5031$ (a), (c) (1958), and by article 0734 of the Navy Regulations, which were expressly approved by President Truman on August 9, 1948, in accordance with 10 U.S.C. $\$ 6011$ (1958), and also "in the light of the historically unquestioned power of a commanding officer summarily to exclude civilians from the area of his command ..." 367 U.S. at 890-94. 
base its holding on the privilege doctrine ${ }^{54}$ but balanced the private interest impaired ${ }^{55}$ against the government power exercised ${ }^{56}$ and determined that the extent of deprivation involved was extremely slight since the petitioner's employment opportunities had in no way been limited. ${ }^{57}$ Accordingly, any impairment of the government power exercised would be unwarranted. ${ }^{5}$

\section{Balancing the Interest Represented by the Indvidual Against THE INTEREST REPRESENTED BY THE GOVERNMENT}

\section{A. Minimal Notice and Hearing}

The results in Homer and Dixon follow logically from Parker and the Greene dictum, but superficially appear contrary to Cafeteria Workers. However, their different results are consistent when the cases are analyzed in terms of a balance between the interests of the individual-determined by ascertaining the predictable injury to the individual in terms both of economic prejudice and of impairment of substantive constitutional rights through the penalizing of past behavior which might have been constitutionally protected and through the deterrent effect on others of such penalties-and the government interest-determined by considering the pre-

54 The Court recognized that "this question cannot be answered by easy assertion that, because she had no constitutional right to be there in the first place, she was not deprived of liberty or property by the Superintendent's action." Id. at 894. The privilege doctrine is only a superficial tautology: "[W] henever a governmental body acts so as to injure an individual, the Constitution requires that the act be consonant with due process of law." Dixon v. Alabama State Bd. of Educ., 294 F.2d 150, 155 (5th Cir.), cert. denied, 368 U.S. 930 (1961). See also HART \& WechsLer, The Federal Courts and the Federal System 332-34 (1953). It is true, of course, that what is "due" will vary according to the governmental and individual interests involved. See Cafeteria Workers v. McElroy, 367 U.S. 886, 895 (1961) ; Joint AntiFascist Refugee Comm. v. McGrath, 341 U.S. 123, 162-63 (1951) (Frankfurter, J., concurring).

55 It can be inferred from the Court's reasoning, 367 U.S. at $898-99$, that there was an underlying feeling that petitioner would have been more prejudiced in employment opportunities by disclosure of the specific reasons for her exclusion from the installation. By implying that procedural requirements might have a deleterious rather than a protective effect, the Court has forgotten that the reasons for requesting procedural safeguards must be determined by the individual and that it is for the Government to decide only whether it is desirable or constitutionally compelled to accord those protections, not to attempt to rethink the petitioner's decision of what is in her own best interests.

56 "[T] he governmental function operating here was not the power to regulate or license, as a lawmaker, an entire trade or profession, or to control an entire branch of private business...." Id. at 896 .

57 In a footnote the Court pointed out that "in oral argument government counsel emphatically represented that denial of access to the Gun Factory would not by law or in fact' prevent Rachel Brawner from obtaining employment on any other federal property." Id. at 899 n.10. The Court, therefore, distinguished this case from Wieman on the grounds that "this is not a case where government action has operated to bestow a badge of disloyalty or infamy, with an attendant foreclosure from other employment opportunity." Id. at 898 .

58 The Court appeared also to say that since substantive due process requirements have been met-the announced grounds were "entirely rational" - petitioner had no right to the safeguards of procedural due process. Id. at 898 . This reasoning was vigorously attacked by the dissent. Id. at 900-01. 
cise nature of the interest involved, the power exercised, and the potential impairment of both by according notice and hearing.59

\section{The Interest Represented by the Individual}

\section{Predictable Economic Injury}

In determining the economic injury involved in the exclusionary action cases, the courts have looked almost without exception to that injury which was sustained in fact. ${ }^{60}$ However, examination of the actual injury which was suffered can be a misleading venture. Its only legitimate purpose is to demonstrate by particularizing under certain circumstances what economic injury should have been foreseeable-the probability or possibility that severe or appreciable economic injury would result from the government action. For these purposes, an "appreciable" economic injury is defined in terms of substantial difficulty in obtaining similar employment within the chosen field. "Severe" injury encompasses either an almost total foreclosure of chosen employment or significant economic prejudice in terms of decrease in earning capacity. What injury actually did occur in the particular case will usually be indicative of what might most reasonably have been anticipated as the effect of the government action upon the individual. ${ }^{\text {.1 }}$ In both Homer and Cafeteria Workers, the actual economic injury suffered was predictable with reasonable certainty. In Homer, if the applicants were not licensed, they would be precluded from all Merchant Marine employment in their chosen vocation of radiotelegraph operator-a severe economic injury. This is exactly what occurred. Further, their particular technical competence, as evidenced by the terms of their FCC license, quite narrowly limited their opportunities for other similar employment. ${ }^{62}$ In Cafeteria Workers, the most reason-

59 In Joint Anti-Fascist Refugee Comm. v. McGrath, 341 U.S. 123, 163 (1951), Frankfurter, J., in concurrence stated:

[F]air play ... cannot, therefore, be tested by mere generalities or sentiments abstractly appealing. The precise nature of the interest that has been adversely affected, the manner in which this was done, the reasons for doing it, the available alternatives to the procedure that was followed, the protection implicit in the office of the functionary whose conduct is challenged, the balance of hurt complained of and good accomplished-these are some of the considerations that must enter into the judicial judgment.

60 See Cafeteria Workers v. McElroy, 367 U.S. 886, 888, 896, 898-99 (1961); Greene v. McElroy, 360 U.S. 474, 486-87, 492 (1959), reversing 254 F.2d 944, 952-53 (D.C. Cir. 1958); Homer v. Richmond, 292 F.2d 719, 722 (D.C. Cir. 1961) ; Parker v. Lester, 227 F.2d 708, 713 (9th Cir. 1955). But see Wieman v. Updegraff, 344 U.S. 183, 190-91 (1952) ; Dixon v. Alabama State Bd. of Educ., 294 F.2d 150, 157 (5th Cir.), cert. denied, 368 U.S. 930 (1961).

61 The initial prediction of probable economic injury must be made by the regulation drafter or administrator of the program. A court, faced with the problem of whether in a certain factual setting the requirements of due process have been provided, must judge this prior determination of probable or possible effect upon the individual and, in so doing, establish more fully articulated standards by which future administrative decisions as to the requirements of due process can be made correctly.

62 See Joint Appendix to Briefs of Appellants and Appellee, pp. 56a-57a, Homer v. Richmond, 292 F.2d 719 (D.C. Cir. 1961). 
able prediction was that as a result of the government action the shortorder cook would encounter little difficulty in obtaining similar work in her chosen field and, therefore, would lose employment only at that particular cafeteria-which the Court in fact determined was the result of the government action. ${ }^{63}$ There was, therefore, only a possibility of appreciable economic injury and only a slight possibility of severe economic injury. It is highly unlikely that a short-order cook would have extreme difficulty in securing other employment as a cook or sustain a substantial decrease in earning capacity as a result of the government action. In addition, because of both the close relation to national security of the chosen occupations of appellants in Homer ${ }^{64}$ and the more specific delineation of the charges against them, the stigma which attached to them by their being denied a license because of alleged extensive communist activities ${ }^{65}$ involved far more danger of potential economic prejudice to them than would any unfavorable inferences which might be drawn from the cook's exclusion for security reasons in Cafeteria Workers. ${ }^{68}$ Thus, in Homer, probability of not only appreciable but severe economic injury as a result of the government action should be placed on the side of the balance representing the individual interest; whereas, in Cafeteria Workers, the individual interest must be characterized as only a possibility of appreciable and a slight possibility of severe economic injury. There was very little evidence offered in Dixon of the actual extent of the economic injury suffered.67 In determining the predictable extent of the economic injury which might be sustained, hindsight reveals only that the expelled students lost the opportunity to attend the particular college, just as the short-order cook lost her particular employment. However, it is probable that a student expelled from college will encounter considerable difficulty in securing admission to other colleges and in obtaining future employment ${ }^{68}$-certainly

63 The Court stated: "[T] he private interest affected ... most assuredly was not the right to follow a chosen trade or profession. . . Rachel Brawner remained entirely free to obtain employment as a short-order cook or to get any other job ... All that was denied her was the opportunity to work at one isolated and specific military installation." 367 U.S. at 895-96. Petitioner was in fact offered employment in another restaurant operated by her employer but refused this job because the location was inconvenient. Id. at 888 .

64 Much employment in the radiotelegraph communications field has some connection with national security, and appellants, charged with extensive subversive associations, would doubtless be unemployable in a good number of the positions in this entire field.

65 See note 9 supra.

66 The Court evidently determined that in fact no rational basis for suspicions of disloyalty was present in the government's exclusionary action. 367 U.S. at 899. But see Cafeteria Workers v. McElroy, 284 F.2d 173, 193 (D.C. Cir. 1960) (Fahy, J., dissenting).

67 This is mainly because of the relative swiftness with which the case came to trial. The court did find that the students "would. . . be injured by the interruption of their course of studies in mid-term." Dixon v. Alabama State Bd. of Educ., 294 F.2d 150, 157 (5th Cir. 1961).

68 The court stated, "It is most unlikely that a public college would accept a student expelled from another public college of the same state. Indeed, expulsion may well prejudice the student in completing his education at any other institution." Ibid. If the student in question is dependent on state subsidy, and if, because of his 
an appreciable injury. If the government action deprives him of the opportunity to attend any college-a possible result-the limitation on employment and the attendant economic prejudice will be severe. ${ }^{69}$

\section{Effect on Substantive Constitutional Rights}

Government exclusionary action, through economic injury, may also jeopardize other constitutional rights by penalizing activity which may be constitutionally protected. When the exercise of constitutionally protected rights might be so penalized by government action, due process may require more procedural safeguards for the individual in order to determine whether these rights were in fact abridged.70 The constitutional rights of the individual are important both to the individual concerned and to that portion of the public which might be deterred from pursuing a constitutionally protected course of conduct. ${ }^{71}$

In Homer, the appellants' rights of free association and freedom of belief may well have been impaired by the failure to accord them the opportunity to explain their previous conduct in answer to charges of Communist party membership, associations, or activities. Although the court stated that the charged activities would be sufficient substantive grounds to justify the Commandant's action, ${ }^{72}$ the absence of the opportunity to demonstrate the falsity of the charges posed a severe threat ${ }^{73}$ to possibly constitutionally protected behavior. ${ }^{74}$ Further, if Homer had held that the Government could deny certification to appellants without any notice or hearing, persons who might be engaged in or contemplating the same or

race, fewer private or public educational institutions are open to him, his expulsion will be even more serious. A bare notation of expulsion, without inclusion of the grounds on which the college action was based, would probably prove more prejudicial to the student's future job opportunities than would a notation articulating the reasons for the expulsion. In contrast, an employee who has been fired arbitrarily will probably be less prejudiced than one fired for specific, publicized security reasons.

69 The court stated, "Without sufficient education the plaintiffs would not be able to earn an adequate livelihood, to enjoy life to the fullest, or to fulfill as completely as possible the duties and responsibilities of good citizens." Ibid. This injury may be more severe in the case of a Negro whose ability to secure any well-paid employment may be almost entirely dependent on his possession of a college diploma.

70 See Speiser v. Randall, 357 U.S. 513, 521 (1958) ("When the State undertakes to restrain unlawful advocacy it must provide procedures which are adequate to safeguard against infringement of constitutionally protected rights. . ."); cf. Cantwell v. Connecticut, 310 U.S. 296, 308-11 (1940); Garner v. Louisiana, 368 U.S. 157, 200-07 (1961) (Harlan, J., concurring). See generally Note, The Void-ForVagueness Doctrine in the Supreme Court, 109 U. PA. L. REv. 67, 75-85, 99-104 (1960).

71 Cf. United States v. Wood, 295 F.2d 772, 780 (5th Cir. 1961), petition for cert. filed, 30 U.S.L. WEeK 3274 (U.S. Feb. 27, 1962) (No. 753). This effect on the exercise of other constitutional rights, either those of the individual concerned or of others in similar situations, has never been judicially recognized as an appropriate factor to place on the balance on behalf of the interest represented by the individual.

72 Homer v. Richmond, 292 F.2d 719, 723-24 (D.C. Cir. 1961).

73 The severity of the penalty must always be measured by the extent of predictable economic injury-in Homer a probability of severe injury.

${ }^{74}$ Cf. Speiser v. Randall, 357 U.S. 513, 520-29 (1958). 
similarly regulated employment would probably be deterred from free association with individuals and organizations because they feared that they someday might be subject to noncertification without opportunity to establish the innocence of their prior activities.

In Cafeteria Workers, the cook, by being afforded no opportunity to deny or explain away any charges which might be levied against her, may suffer some penalty for activities which might have been protected by freedom of belief and association. However, since it was probable that she could obtain other employment, the severity of this penalty is not great. Nor would others be likely to be deterred from protected activities by the decision; the relatively mild penalty combined with the very general "security reasons" explanation for the exclusion would not excite the same public apprehension which might have been aroused by the specifically enumerated alleged activities in Homer.

The students in Dixon were penalized for engaging in sit-ins at lunch counters in a publicly owned building, ${ }^{75}$ an activity which may come within the constitutional protection of fourteenth amendment equal protection ${ }^{76}$ and first amendment freedom of speech. ${ }^{77}$ The penalty here, measured in terms of predictable economic injury, is quite substantial. ${ }^{78}$ Also, it is probable that similar students, in fear of expulsion without opportunity to justify their actions, may be deterred from engaging in these activities.

\section{The Interest Represented by the Government}

The nature of the government power exercised in each of the cases must also be considered. In Homer, the Government, operating in a field extrinsic to essential government operation on the basis of the admiralty and maritime powers, assumed the role of licensing all who sought to pursue a particular private employment. In Cafeteria Workers, by determining the right of access to the installation of a person privately employed on government property, the Government was exercising its historic right to manage the internal affairs of a military establishment ${ }^{78}$-an exercise of power inherent in a sovereign nation. In Dixon, the state was also exercising its proprietary power, but a less fundamental one than in Cafeteria Workers-the management of a state college. In both Homer and Cafeteria Workers, the Government concern which had motivated the action

75 Dixon v. Alabama State Bd. of Educ., 294 F.2d 150, 152 (5th Cir. 1961). All of the expelled students participated in a sit-in "in the lunch grill located in the basement of the Montgomery County Courthouse."

76 See Turner v. City of Memphis, 369 U.S. 350 (1962) (per curiam) ; Burton v. Wilmington Parking Authority, 365 U.S. 715, 723-26 (1961). Turner and Burton make it clear that the students would have had a right to be served at the courthouse grill lunch counter but do not necessarily give them the right to demonstrate in numbers to obtain that service.

77 See Garner v. Louisiana, 368 U.S. 157, 201-03 (1961) (Harlan, J., concurring).

78 See notes 67-69 supra and accompanying text.

79 Cafeteria Workers v. McElroy, 367 U.S. 886, 892-94 (1961) ; cf. Perkins v. Lukens Steel Co., 310 U.S. 113, 129 (1940). See also Vitarelli v. Seaton, 359 U.S. 535, 539 (1959) (dictum). Compare Greene v. McElroy, 360 U.S. 474, $493-94$ (1959). 
was its interest in national security. In Homer, the concern was for security in a general sense; in Cafeteria Workers, the Government acted to protect the security of the particular base as well as overall national security. In this sense, the government action there was more closely interrelated with the government power exercised than in Homer. In Dixon, the government power exercised was motivated by an important but not preeminent concern - the maintenance of the educational atmosphere of the college.

Part of the threat to the government interest in both Homer and Cafeteria Workers was that requiring notice of charges in detail might endanger national security by revealing confidential sources-clearly not a concern in Dixon. However, in all of the cases, establishing and maintaining a program providing notice and hearing would entail a certain amount of government time, trouble, and expense, which must be weighed against the individual interests supporting such notice and hearing.

On the other hand, the Government also has a positive interest in providing fair hearing procedures in order both to reach the best decision ${ }^{80}$ and to appear to its citizens to be fair. In Homer and Cafeteria Workers, the government interest, as well as protecting confidential information in the interests of national security, includes providing a program which offers to the individual maximum protection consistent with national security. ${ }^{81}$ This positive concern may reduce any impairment which might result from the inconvenience in providing the program. In Dixon, the state's positive interest in determining the truth, in maintaining a feeling of student confidence in the fairness of the administration, and, above all, in promoting the free exchange of ideas in the college community neutralizes any impairment to the exercised state power due to inconvenience. ${ }^{82}$

\section{Conclusion}

Thus, in Homer, the interest of the individual-stated in terms of a probability of severe economic injury, severe penalty for past behavior which might have been constitutionally protected, and the likely deterrence of others in a similar position from constitutionally protected conductjustifies the risk to national security and the hindrance of the governmental prerogative which would result from according notice and hearing. In Cafeteria Workers the relatively slight individual interest-only a slight

80 Cf. 10 C.F.R. $\$ 4.32$ (1959) (Atomic Energy Commission regulation requiring "due recognition to . . the value of the individual's services to the atomic energy program ...") ; ASs' $N$ OF THE BAR of THE CITY OF NEW YORK, REPORT OF THE Special Commitree on the Federal Loyalty-Security Program 149-51 (1956) (recommending that "due weight ... [should be given] to the value of the individual to the public service.")

81 The first amendment manifests the government's interest in promoting the free interchange of ideas, especially political ones. See Roth v. United States, 354 U.S. 476, 484 (1957) (dictum).

82 Such interests probably explain the almost invariable practice of colleges to provide at least some type of notice and hearing. See notes 30-32 supra and accompanying text. 
possibility of appreciable economic injury, a slight penalty for past behavior which might have been constitutionally protected, and little possibility of a deterrent effect-does not merit endangering the national security to the extent which would have been necessitated if notice and hearing were to be accorded. And in Dixon, the not insubstantial individual interest-a probability of at least appreciable economic injury, a significant penalty for possibly constitutionally protected behavior and a probable deterrence of similar students from engaging in constitutionally protected conduct-warrants the requirement of notice and hearing since, as has been suggested, the importance of public fairness in the educational process more than offsets the inconvenience of granting a hearing-which inconvenience is the only justification for denying notice and hearing in the Dixon area. Thus, the results of the three cases are consistent: in Cafeteria Workers, the government's fundamental power and paramount security concern overbalance the relatively insubstantial individual interest; the extremely important interests represented by the individual in Homer outweigh the strong government interest; and in Dixon the minimal government interest is overcome by at least a substantial individual interest. The facts of both Homer and Dixon call for at least minimal notice and hearing; the circumstances of Cafeteria Workers do not. ${ }^{83}$

$83 \mathrm{~A}$ requirement of notice and hearing cannot be understood as embodying one combination of procedural safeguards in every case in which a court determines that procedural due process requires notice and hearing. "Hearing" must be examined in the specific factual context of each case. "Notice" is a more static concept which generally requires that a written statement, containing specific charges and the grounds on which they are based, be delivered to the individual whose employment is in jeopardy sufficiently in advance of final determination of his case to enable him to prepare his defense to the charges and their grounds; but it also depends in some measure on the factual circumstances of each case. In some cases, usually dependent on the type of hearing which will be required, notice might have to include an enumeration of the sources of the government's charges, revelation of informants' names, and the nature of the information that they supplied. Under a particular set of facts no form of notice or hearing whatever may be demanded by procedural due process. See Joint Anti-Fascist Refugee Comm. v. McGrath, 341 U.S. 123, 162-63 (1951) (concurring opinion), for a discussion of due process as a relative concept. An administrative hearing which would be commensurate with due process of law under varying factual circumstances could entail any or all of the following protections: the right to be represented by counsel; the right to meet by oral argument the charges detailed in the notice; the right to present a defense to the charges by oral and documentary evidence; the right to subpoena reluctant witnesses for direct testimony; and the right to be confronted at the hearing with the government's case or to be granted a subpoena power over government informants in order to subject them to cross-examination. In Homer and Dixon, it could be maintained that some form of notice was given, see text accompanying notes 84,91 infra, but in Cafeteria Workers there was none, 367 U.S. at 897 . In all three cases, however, since none of the appellants received any official hearings prior to the government exclusionary action, their due process contentions could be limited to demands for a minimal type of hearing; in none of these cases did appellants have to detail the specific nature of the hearing which they were arguing was required by due process of law. However, to comprehend the significance of the due process which the Homer and Dixon courts required of the government, an examination should be made of the specific type of hearing which the Constitution would require of the government in order to protect the interests of appellants in both cases. The abstract determination that due process of law requires some notice and some hearing under the circumstances involved in those cases fails to clarify the particular protections which the Constitution does and does not require in the fifth and fourteenth amendment due process clauses. 


\section{B. The Extent of the Notice and Hearing Required}

To determine how much notice and hearing is required by the facts of each case, an examination should be made of what procedures were afforded, how additional procedures would have benefited the individual, and whether that benefit would justify the impairment to the government power and interest involved necessitated by affording that degree of notice and hearing. In Homer, the only procedural protection consisted of finally informing the rejected applicants of the grounds on which the Coast Guard based its findings. ${ }^{84}$ The Government had acted on the basis of information about the individuals' past activities and associations. When past behavior is questioned, it is often difficult to locate the witnesses and documentary evidence necessary to disprove the charges. Thus, without notice of the events on which the Government was concentrating to draw its conclusions and the specific charges being levied against the individuals, little could be done in their defense. Given this data in the notice and a hearing complete except for the right of confrontation and cross-examination, the applicants might have been able to defend themselves by some affirmative proof of their behavior during the period in their past on which the Government was focusing its attack. However, even these procedures might not have enabled them to provide an adequate defense; confrontation and cross-examination might have been needed. But such a hearing could be extremely costly to the Government by forcing disclosure of undercover agents. The most reasonable program under the facts of Homer would be to require full procedural protection unless it should be determined that the revelation of confidential sources would seriously impair national security ${ }^{85}$ Much of this procedural protection was actually instituted by the Coast Guard for noncommissioned merchant seamen as a result of the Parker decision.88 Similarly, after Greene, the President inaugurated an industrial personnel security program which provided that there would be full disclosure of confidential information and sources unless the head of the department supplying the information determined that the disclosure of the identity of confidential agents "would be substantially harmful to the national interest," and that the final decision on any individual who was refused disclosure because of such determination could be made only by the head of the department administering the program or his special designee. ${ }^{87}$ By insuring that these crucial decisions will be made by high level executives, this program offers a protection to the individual which is commensurate with due process of law in striking an appropriate balance between the interests represented by the individual and the Government.

\footnotetext{
84 See note 9 supra.

85 See note 43 supra.

86 Ibid.

87 See note 48 supra.
} 
The court of appeals in Dixon, by detailing specific procedures which would be required by due process under the factual circumstances of the case $^{88}$ departed from the normal judicial practice when procedures are found to be deficient in due process safeguards. ${ }^{89}$ The students were in fact given no hearing prior to their expulsion; they received no notice prior to the state action except for warnings-both general and personal-from the college president to refrain from participation in further activities which might disrupt college order, other students' studies, or the studies of the participating students. ${ }^{90}$ Each was sent a letter by the college president informing him of his expulsion and containing the regulations governing expulsion which had been adopted and published by the state board of education. ${ }^{91}$ The district court found that all of the expelled students participated in at least one of the demonstrations and that several took part in the other activities.92 These findings do not appear to have been controverted by the students. ${ }^{93}$ Thus, the question for decision at the hearing would be whether, under the regulations, the students' actions were of such a nature as to justify expulsion. ${ }^{94}$ Their motives and reasons for organizing and participating in the activities would have been essential to a determination of whether their conduct had been insubordinate. ${ }^{95}$ For this purpose, a hearing at which they could have presented their version of the facts and explained their actions would have afforded minimum protection. Further, since, as the court pointed out, the testimony of witnesses about segregation demonstrations would be likely to be colored by their particular points of view, ${ }^{96}$ it would seem that in order to enable the

88 Dixon v. Alabama State Bd. of Educ., 294 F.2d 150, 159 (5th Cir. 1961).

89 See Parker v. Lester, 227 F.2d 708, 723-24 (9th Cir. 1955).

90294 F.2d at 152 n.3, 161.

01 Id. at 151-52 n.2. The Alabama State Board of Education Regulations included in the letter from the college president were:

Pupils may be expelled from any of the Colleges: a. For willful disobedience

to the rules and regulations established for the conduct of the schools.

b. For willful and continued neglect of studies and continued failure to maintain the standards of efficiency required by the rules and regulations.

c. For Conduct Prejudicial to the School and for Conduct Unbecoming a

Student or Future Teacher in Schools of Alabama, for Insubordination and

Insurrection, or for Inciting Other Pupils to Like Conduct.

d. For any conduct involving moral turpitude.

In the notice received by the students the words in paragraph "c $c$ " were capitalized. $1960)$.

92 Dixon v. Alabama State Bd. of Educ., 186 F. Supp. 945, 947-48 (M.D Ala.

93 The dissenting opinion in Dixon, 294 F.2d at 163, noted "that only one of the appellants took the witness stand in the court below, although they all announced at the outset that they were ready for trial and manifestly were present in court. Their presence and participation in all which transpired was shown by believable evidence and circumstances and stand wholly undenied."

94 Cf. Knight v. State Bd. of Educ., 200 F. Supp. 174 (M.D. Tenn. 1961). Most likely an argument on penalty for constitutionally protected activity would not be raised at the administrative hearing; but it would be relevant if the administrator would entertain it.

95 See note 91 supra.

96 Dixon v. Alabama State Bd. of Educ., 294 F.2d 150, 158-59 (5th Cir. 1961). 
students to prepare an adequate defense, they should be supplied with the names and the substance of the testimony of the witnesses against them. The court decided that all this procedural protection was required by due process; however, it did not require the further protection of confrontation and cross-examination at the hearing ${ }^{97}$ since it was concerned-legitimately so-with the effect of detrimental publicity ${ }^{98}$ on the college. ${ }^{99}$ However, this danger could have been minimized by combining a full hearing with safeguards against disorderly behavior which might discredit the college. This procedure would have afforded maximum protection to the students' interests, and, unlike the situation of revelation of confidential sources facing the Government in the licensing and public employment discharge cases in which national security is concerned, the state appears here to have no substantial reason for not according full safeguards.

$$
\text { * * * }
$$

The considerations which show that Homer and Dixon are consistent with Cafeteria Workers demonstrate that Cafeteria Workers, in refusing to extend any procedural due process safeguards to the relatively minor individual interest there involved, has not placed undue limitation upon the protection provided by both fifth and fourteenth amendment due process to those individual interests which have been more seriously impaired by government action.

J.R.S.

97 It is not clear whether in making this determination the court was saying that confrontation and cross-examination were not required by due process under the Dixon facts or that the specific procedural protection beyond those procedures expressly enumerated by the court should be determined initially by the state board of education. The latter construction would not prevent the court from later holding that the procedures provided were still not consistent with due process.

98 The textual statement assumes that the court's recognition of the state's concern in preventing adverse publicity was based solely on consideration of that publicity which might result from a disorderly hearing, and not of that publicity which would result from full disclosure of what the college was doing. A state has no legitimate interest in repressing this latter type of publicity.

99 Dixon v. Alabama State Bd. of Educ., 294 F.2d 150, 159 (5th Cir. 1961). 